\title{
LA RECREACIÓN HUMORÍSTICO-PARÓDICA DEL JUICIO DE LA RISA EN EL ASNO DE ORO DE APULEYO
}

\author{
Irene Rojas $R$.
}

\begin{abstract}
RESUMEN
El siguiente artículo presenta el episodio del juicio de Lucio en el Festival de la risa en el texto El asno de oro del escritor latino Apuleyo (125 d.C.). Las escenas parodian los aspectos histriónicos del discurso forense como efecto cómico. La aventura de Lucio prepara la visión del héroe novelístico de acuerdo con el rito de coronación-destronamiento del rey del carnaval.
\end{abstract}

\section{ABSTRACT}

The next paper presents the episode of Lucius' trial at the Festival of Laughter in the text The Golden Ass by the Latin writer Apuleius (125 d. C.). These scenes parody histrionic aspects of forensic speeches for comic effect. Lucius' adventure prepares the vision of the novelistic hero in agreement with the coronation-dethronement rite of the carnival king.

Cada una de las formas estilísticas del texto El asno de oro se encuentra ligada a determinadas posibilidades dialógico-narrativas y requiere específicas formas de elaboración de los lenguajes. Entre estas generalidades, se encuentra la recreación humorístico-paródica de numerosos estratos de la lengua. Su estilo expresa diversas presentaciones de la lengua literaria; entre estas modalidades, se desarrollan las mixtificaciones de la elocuencia parlamentaria, la representación jurídica y las formas de protocolo, entre otras.

Así, Apuleyo destaca la estilización paródica del lenguaje de los discursos solemnes en el episodio del juicio del Festival de la risa. El paso de este estilo viene preparado por las frases que se mantienen, desde el comienzo mismo, con tonos épicos y solemnes. Tales características explican cómo la diversidad de lenguas y no la unidad de la lengua general normativa dispone la base del estilo de Apuleyo. En este sentido, el mismo autor explica en el pró$\operatorname{logo}^{1}$ de El asno de oro la notoria presentación de su metamorfosis estilística:

[...] siquid exotici ac forensis sermonis rudis locutor offendero. iam haec equidem ipsa uocis immutatio desultoriae scientiae stilo quem accesimus respondet ${ }^{2}$ (Apuleius: I-I) .

\section{El juicio del Festival de la risa}

La ciudad de Hípata en Tesalia celebra una fiesta en honor del dios de la Risa, cuando el preocupado Lucio es detenido y llevado a juicio para responder a las tres muertes de la 
noche anterior. El juicio se celebra en un teatro debido a la numerosa cantidad de espectadores. La recreación humorístico-paródica del género judicial se realiza frente a un auditorio de jueces o magistrados y se efectúa en un clima serio, aunque a la vez cómico. Todo se encuentra dispuesto; el aterrorizado Lucio es conducido al proscenio como si fuera una víctima y es colocado en mitad de la orquesta. Los magistrados ocupan un lugar imponente y de altura. En este episodio, la carnavalización sale a la superficie y Lucio observa desde el espacio de lo bajo, en contraposición con lo alto. La narración expresa la topología de este proceso, antes y durante el juicio, de camino a la plaza y al teatro:

\footnotetext{
et quanquam capite in terram, immo ad ipsos inferos iam deiecto maestus incederem, obliquato tamen aspectu rem admirationis maximae conspicio: nam inter tot milia populi circumsedentis nemo prorsum, qui non risu dirumperetur aderat ${ }^{3}$ (Apuleius: III-II).
}

En este episodio, se representa la imagen del destronamiento y la universal ridiculización del rey usurpador del carnaval en la plaza. Y en esta festividad, el inusitado interés de los lugareños los hace desdeñar hasta su propia seguridad, y estos se colocan en lugares estratégicos para captar una mejor visión del juicio. Todo el pueblo llenó el recinto con asombrosa rapidez: la entrada y el techo estaban abarrotados; había personas asidas a las columnas; otros se subían a las estatuas; algunos, incluso, se asomaban a los tragaluces del artesonado. Este espacio, de acuerdo con la simbología carnavalesca, conforma la mixtificación del drama forense: lo alto, con respecto a los magistrados y lo bajo, según la posición de Lucio:

\begin{abstract}
nec mora, cum passim populus procurrens caueae conseptum mira caleritate conpleuit; aditus etiam et tectum omne fartim stipauerant. plerique columnis implexi, alii statuis dependuli, nonnuli per fenestras et lacunaria semiconspicui, miro tamen omnes studio uisendi pericula salutis neclegebant ${ }^{4}$ (Apuleius: III-II).
\end{abstract}

El acusador es el prefecto de la vigilancia nocturna y argumenta que nadie debe poner en duda el celo que ha tenido para cumplir con sus deberes. Entre las pruebas que dependen del conmover, se encuentra el departamento de la retórica psicológica. Los atributos del orador, los caracteres, los tonos, los aires (ethe) son los rasgos que se deben mostrar al auditorio para causar buena impresión (Barthes 1974: 63). Así, el acusador de Lucio representa una figura de experiencia y sabiduría, gravedad y elocuencia (fronesis). Se expresa como un hombre mayor o anciano (acussator quidam senior) que tiene una voz extraordinaria o imponente (immanem uocem). Asimismo, denota respeto y complicidad con el auditorio (eunoia).

En el exordio, el acusador intenta lograr la seducción del auditorio (captatio benevolentiae) y, a la vez, trata de obtener los favores de los magistrados. Así, la retórica forense o legal refiere siempre al pasado, buscando establecer la justicia o injusticia de una acción, ya sea acusando o defendiendo:

\footnotetext{
Neque praua res ac praecipue pacem ciuitatis cunctae respiciens [...] Quirites sanctissimi. quare magis congruit sedulo singulos atque uniuersos uos pro dignitate publica priuidere, ne nefarius homicida tot caedium lanienam, quam cruenter exercuit, inpune commisserit ${ }^{5}$ (Apuleius: III-III).
}

El esfuerzo del orador trata de ganar la total aceptación por parte del auditorio. La argumentación es un acto del orador sobre el auditorio y tiende a desencadenar una reacción de este último para comprometerlo con un determinado punto de vista (Monsalve 1992: 52). Tanto el enfoque como el desarrollo de la argumentación presuponen el acuerdo 
del auditorio. Esto se da en lo referente al contenido de las premisas, las ligazones que se utilizan y la manera como se sirven de ellas. La elección de las premisas y la manera de formularlas expresan por sí mismas un valor argumentativo, porque representan un primer paso en la estrategia de persuasión (Monsalve 1992: 71).

El acusador, según sus argumentos, fue testigo de la despiadada matanza cometida por Lucio. La vehemencia del discurso, la descripción detallada y patética, la precisión con que trata de asociar los diversos hechos, la específica caracterización del acusado, lo reprochable de la sanguinaria y brutal acometida son características esenciales de un fuerte argumento que intenta ganar eficacia y la mayor adherencia posible para evitar al máximo su refutación. Así, a la narratio o exposición de los hechos, le sigue la confirmatio o exposición de los argumentos; es aquí donde se enuncian las "pruebas" elaboradas en el curso de la inventio (Barthes 1974: 70).

[...] conspicio istum crudelissimum iuuenem mucrone destricto passim caedibus operantem iamque tris numero saeuitia eius interemptos ante pedes ipsius spirantibus adhuc corporibus in multo sanguine palpitantes $^{6}$ (Apuleius: III-III).

Los lugares especiales del discurso judicial se denominan status causae, los cuales componen el corazón de la quaestio; el punto que se debe juzgar es el momento en que se produce el primer choque entre los adversarios. De esta forma, se clasifican tres status causae:

1) An sit? La conjetura: el hecho tuvo lugar o no; esta situación expresa un conflicto de aserciones. Se formula la aseveración FECISTI. En el juicio de la risa, la recreación humorístico-paródica se ocupa de las diferencias y los conflictos entre la experiencia observada (fantástica o producto de la invención) y la lógica, la apariencia y la realidad.

2) Quid sit? La definición: determina la clasificación legal del hecho; se trata de definir la situación como un crimen, una masacre o ignominia para la paz y la seguridad pública que debía ser objeto de un proceso sacramental.

3) Quale sit? La cualidad: se cuestiona si el hecho es permitido, útil o excusable. La fiscalía propone que el acto es reprochable y siniestro y no puede quedar impune. Así, la opinión pública debe enardecer su indignación y un proceso judicial daría su veredicto.

El acusador afirma que él relatará puntualmente los acontecimientos de esa noche; especifica que su trabajo como custodio es merecedor de toda confianza y declara que su vigilia es efectuada con una escrupulosa diligencia (scrupulosa diligentia). Así, enuncia una información que no teme a las consecuencias y trata de demostrar su fuerza y denotar la fidelidad que tiene para mantener la seguridad de la ciudad y, expresa, mediante frases directas, la impresión de una fuerza teatral (pathos):

sed prouidentia deum, quae nihil impunitum nocentibus permittit, priusquam iste clandestinis itineribus elaberetur, mane praestolatus ad grauissimum iudicii uestri sacramentum eum curaui perducere ${ }^{7}$ (Apuleius: III-III).

La exposición del acusador refuerza una expresividad dramático-emotiva, con lo que logra provocar las pruebas psicológicas de un acto cruel y despiadado. Sus argumentos tratan 
de influir en los sentimientos del público (pathe) y suscitan la experimentación de diversos estados del ánimo: temor, cólera, indignación, odio, repulsión, etc.

\footnotetext{
habetis itaque reum tot caedibus impiatum, reum coram depresum, reum peregrinum. constanter itaque in hominem alienum ferte sententias de eo crimine, quod etiam in uestrum ciuem seueriter uindicaretis ${ }^{8}$ (Apuleius III-III).
}

Según la exposición del acusador, Lucio, metamorfoseado en reo, tiene a su haber la atroz muerte de tres hombres y el proceso judicial caracteriza su ignominia por medio de la expresión acumulativa de las frases que repasan la posición de Lucio como un despiadado reo extranjero, quien no está implicado con los vínculos de la ciudad ni con los habitantes. La perífrasis peyorativa configura la línea ascendente de su "criminalidad". De esta forma, se expresa la credibilidad de un consabido crimen. Se formulan premisas para clasificar los argumentos (topoi) y fundamentar valores o jerarquías que aumenten la adhesión a ellos: lo probable/improbable, lo real/irreal, lo existente/inexistente, verdadero/falso (Barthes 1974: 60).

\section{Pro Lucio Lucii}

Luego de la intervención del acusador, el portavoz le pregunta a Lucio si tiene algo que decir; pero el pathos de la tristeza y lo fantástico de la situación habían trastocado los ánimos de Lucio, quien entonces no podía hacer nada más que llorar (At ego nihil tunc temporibus amplius quam flere poteram III-IV). Y Lucio, movido, según él, por una inspiración divina, expresa en su exordio lo difícil que es persuadir a la multitud de que es inocente, pues tiene los tres cadáveres de los ciudadanos en frente. Pero, aunque la benevolencia pública le conceda poca atención, afirma que va a demostrar que no fue su culpa, sino la casualidad de los hechos lo que ha provocado la indignación de los jueces y de los espectadores:

\footnotetext{
Nam cum a cena me serius aliquando reciperem, potulentus alioquin, quod plane uerum crimen meum non diffitebor, ante ipsas fores hospitii -ad bonum autem Milonem ciuem uestrum deuorto- uideo quosdam saeuissimos latrones aditum temptantes et domus ianuas cardinibus obtortis euellere gestientes claustrisque omnibus, quae accuratissime adfixa fuerant, uiolenter euulsis secum iam de inhabitantium exitio deliberantes. unus denique et manu promptior et corpore uastior his asfatibus et ceteros incitabat: "heus pueri, quam maribus animis et uiribus alacribus dormientes adgrediamur [...]" ${ }^{9}$ (Apuleius: III-V).
}

El razonamiento del género judicial se realiza por medio de los entimemas (silogismos retóricos) para presentar el análisis de una deducción que procura persuadir (Barthes 1974: 49-50). Lucio expone que unos feroces y violentos bandidos atacaban el umbral de la casa de Milón y deseaban romper las cerraduras y agredir a sus cercanos huéspedes con las espadas, ya que pretendían provocar una sangrienta matanza. Entonces, debido a la salvaje acometida, Lucio se vio obligado a atacarlos y herirlos varias veces, por lo cual el asesinato estaría permitido en defensa personal y sería un móvil para proteger la integridad de los débiles moradores de la casa. De esta manera, Lucio, como prueba de los hechos, hace notar sus obligaciones de buen ciudadano, ya que debió proteger a sus huéspedes y a sí mismo, y tuvo que poner en fuga a tan temibles bandidos. Así, antes de la metamorfosis en Lucio-reo, explica su metamorfosis en Lucio-héroe y aduce que, debido a una inesperada situación, debe ser permitido enfrentarse a quien comete una injuria: 
ipse denique dux et signifer ceterorum ualidis me uiribus adgressus ilico manibus amababus capillo adreptum ac retro reflexum effigere lapide gestit. quem dum sibi porrigi flagitat, certa manu percussum feliciter prosterno. ac mox alium pedibus meis mordicus inhaerentem per scapulas ictu temperato tertimque inprouide accurrentem pectore offenso peremo" ${ }^{10}$ (Apuleius: III-VI).

La figura de Lucio-héroe es presentada en una escena dramática con una fuerza y sonoridad netamente carnavalescas: el pathos deja presenciar las tensiones, las tonalidades de las acometidas, los golpes, las arrastradas, los mordiscos y las estocadas con las espadas; a esto se le suman los posibles gritos, gemidos y gestos de dolor. Lucio, en su peripecia, se caracteriza como un agente activo, supremo y elevado, paradigma de una trascendencia vertical, ya que, debido a la afrenta del $d u x$ y de los otros bandidos, él derriba, acomete y asesina (prosterno, offenso, peremo).

No obstante, esta confrontación se realiza en una situación excéntrica y fuera de lugar y se produce con un estilo irónico, humorístico y paródico, en un tono internamente dialogizado del modelo del héroe tradicional, representante de su colectividad y seguidor de un noble ideal. La narración de los hechos presenta dos lenguajes y dos acentos valorativos. Según esto, la ironía es presentada en la utilización del habla, las imágenes de los personajes y los símbolos, a partir de la selección de las escenas en un orden específico y en la determinación de los rasgos de los personajes. En este caso, la ironía es el medio por el cual Apuleyo busca los límites de las proporciones y desproporciones concebibles. Así, el dialogismo del héroe/antihéroe se deja sentir en el estilo y en el tratamiento de la materia.

Tal elocutio de Apuleyo muestra esa constante y notoria coexistencia de elementos contrarios. La forma básica de la paradoja, el oxímoron, explota la oposición de sentidos. Según la peripecia de Lucio, se puede tomar como un sentimiento ambiguo. Por una parte, actuó ebrio y experimentó ciertos hechos que, en realidad, existe duda de si realmente sucedieron. Por otro lado, Lucio pudo agregar argumentos ficticios para tratar de conseguir su propia salvación y librarse de un fuerte pronunciamiento judicial. Así, numerosos elementos son desarrollados en el dialogismo de las diversas voces: ser/parecer, verdad/mentira, ilusión/realidad, arriba/abajo, etc.

La paradoja retórica de Apuleyo presenta, a la vez, una contradicción que equivoca, miente y dice la verdad y especula acerca de su función u operación. En esta narración, las diversas imágenes parecen contradictorias y paradójicas, ya que la retórica apuleyana pertenece

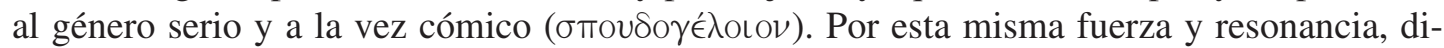
versidad de tonos, ambiguitas y cambios imprevistos, se explica cómo el ludus de Apuleyo busca intencionalmente las construcciones híbridas del lenguaje. Esta anfibología o significado múltiple del vocablo, la imagen, las expresiones o el conjunto de la elocutio enriquecen los conceptos y temas de El asno de oro y, por esta amplificación del significado, Apuleyo es un diletante de la variedad de tonalidades explícitas e implícitas de su dialogismo.

De acuerdo con esta musicalidad apuleyana, la narración denota la incertidumbre del lector, la cual es un estado facultativo de lo fantástico. Esto implica una integración del receptor con el mundo de los personajes y se define por una percepción ambigua que el propio lector tiene de los acontecimientos relatados (Todorov 1974: 41). Según la perspectiva de Luciohéroe, éste considera que debe recibir una valoración pública por su singular y noble aventura:

sic pace uindicata domoque hospitium ac salute communi protecta non tam impunem me, uerum etiam laudabilem publice credebam fore [...] ${ }^{11}$ (Apuleius III-VI). 
Sin embargo, cuando Lucio acaba su elocutio y actio patéticos, observa con sorpresa la reacción del pueblo de Hípata:

$[\ldots]$ conspicio prosus totum populum, risu cachinabili diffluebant $[\ldots]^{12}$ (Apuleius: III-VII).

A continuación, se realiza el pathos escénico de las viudas harapientas y plañideras que piden justicia, venganza y protección para los huérfanos. Y, luego de la siguiente fase del juicio, que consiste en la tortura por medio del fuego y de los látigos para encontrar cómplices y provocar una mayor indignación, surge el momento inesperado del desconcierto y la ridiculización. Y Lucio, a empujones, es obligado a destapar los cadáveres:

Nam cadauera illa iugulatorum hominum erant tres utres inflati uarisque secti foraminibus et, ut uespertinum proelium meum recordabar, his locis hiantes quibus latrones illos uulneraueram ${ }^{13}$ (Apuleius III-IX).

En este episodio, nos enfrentamos a los accesorios característicos del complejo carnavalesco: carcajada/tragedia, el bufón y la multitud carnavalesca. La representación del juicio y la experiencia de Lucio expresan la imagen del destronamiento y la universal ridiculización del rey usurpador del carnaval en la plaza. Apuleyo absorbe esta risa ambivalente, alegre y sarcástica que amortaja y resucita, junto con la tradición genérica de la carnavalización. Esta característica la encontramos en la estructura de las imágenes, así como en numerosas situaciones del argumento y en algunas particularidades del estilo verbal. Su narrativa expresa una percepción del mundo basada en la alegría del cambio y en la jocosa relatividad que se opone a la seriedad unilateral.

Cuando concluye el Juicio de la Risa y descubren a las víctimas, el estupefacto y petrificado Lucio escucha la musicalidad colectiva que preludia su "apoteosis":

\footnotetext{
Tunc ille quorundam astu paulisper cohibitus risus libere iam exarsit in plebem. hi gaudii nimietate graculari, illi dolorem uentris manuum compressione sedare. et certe laetitia delibuti meque respectantes cuncti thaetro facessunt ${ }^{14}$ (Apuleius: III-X).
}

La mezcla de la carnavalización con el argumento de aventuras, los visibles contrastes, los giros paradójicos y el pathos de cambios y transformaciones se expresan de acuerdo con los cambios bruscos y rápidos, con las subidas y bajadas instantáneas y con las entronizaciones y destronamientos en la atmósfera de esta mixtificación del juicio:

[...] fixus in lapidem steti gelidus nihil secus quam una de ceteris theatri statuis uel columnis ${ }^{15}$ (Apuleius: III-X).

La acción carnavalesca principal es la coronación-destronamiento del rey del carnaval. Este rito aparece de un modo elaborado en las saturnales y el texto de El asno de oro mantiene esta forma característica de la alegre relatividad. Todos los momentos simbólicos de esta ceremonia se ubican en otro plano positivo, no se trata de la negación y aniquilación plena y absoluta (Bajtín 1986: 176). Precisamente, en el rito de destronamiento, se manifiesta el pathos de la muerte creativa, porque esta ambigüedad del rito es inseparable y su división absoluta perdería totalmente su sentido carnavalesco. La acción de coronación-destronamiento está compenetrada de categorías carnavalescas: el contacto libre y familiar, las disparidades carnavalescas (presidiario-rey), la recreación humorística, etc. En este sentido, Milón explica los hechos sucedidos a Lucio: 
[...] omnem itaque de tuo pectore praesentem tristitudinem mitte et angorem animi depelle. nam lusus iste, quem publice gratissimo deo Risui per annua reuerticula solemniter celebramus, semper commenti nouitate florescit. iste deus auctorem et $<$ ac- $>$ torem suum propitius ubique comitabitur amanter, nec umquam patietur ut ex animo doleas, sed frontem tuam serena uenustate laetabit adsidue. at tibi ciuitas omnis pro ista gratia honores egregios obtulit $\left[\ldots{ }^{16}\right.$ (Apuleius: III-XX).

Según estas características, cuando Lucio se enfrentó a los odres-bandidos, es metamorfoseado en Lucio-héroe; luego, detenido y enjuiciado, es metamorfoseado en Lucio-reo. Finalmente, ridiculizado y humillado, es metamorfoseado en Lucio-piedra/columna. Y esta última transmutación representa su verticalidad momentánea del rey usurpador del carnaval.

Tal carácter concreto y sensible se relaciona con las formas animadas de las imágenes del espectáculo teatral. Sin embargo, el núcleo del carnaval no representa la forma puramente artística del teatro y, en general, no pertenece al dominio del arte (Bajtín 1995: 12). En realidad, esta recreación se encuentra situada entre las fronteras del arte y la vida del juego. De hecho, el carnaval elimina toda distinción entre actores y espectadores. También ignora la escena, pues de lo contrario el carnaval se destruiría. Los espectadores no asisten al carnaval, sino que lo viven, porque el carnaval está hecho para todo el pueblo. No existe otra vida durante este juego y es imposible escapar, ya que el carnaval no posee ninguna frontera espacial. En el curso de la fiesta, sólo puede vivirse de acuerdo con las leyes de la libertad. Esta esencia del carnaval ofrece un carácter universal y cada individuo participa en su renacimiento y renovación, pues los que intervienen en el regocijo lo experimentan vivamente (Bajtín 1995: 12-3).

La idea del carnaval ha sido observada y se ha manifestado de forma muy sensible en las saturnales romanas, las cuales eran experimentadas como un retorno efectivo y completo (aunque provisorio) al país de la Edad de Oro. Estas tradiciones sobrevivieron en la sátira menipea y en las formas precursoras de la novela moderna. Como memoria de este género, la vida misma juega e interpreta y todo el pueblo entra en comunión e interacción social. Su humor carnavalesco es festivo y no se produce como una reacción individual ante uno u otro hecho "singular" aislado. La risa es, ante todo, patrimonio del pueblo y todos ríen. Además la risa es universal, el mundo parece cómico y es percibido y considerado en un aspecto jocoso. Esta risa es ambivalente y alegre, pero, al mismo tiempo, es burlona y sarcástica, niega y afirma, amortaja y resucita a la vez. Esta cualidad de lo alto y lo bajo de la fiesta popular escarnece a los mismos burladores. El pueblo no se excluye a sí mismo del mundo en evolución (Bajtín 1995: 17). También él se siente incompleto porque muere y nace a la vez. Esta es la característica particular de la risa carnavalesca que se diferencia de la risa puramente satírica.

Entonces, Apuleyo absorbe el carnaval con sus formas y símbolos y los complementa con sus propias particularidades. Esta arquitectónica de la percepción carnavalesca del mundo se convirtió en su poderoso recurso y formó un lenguaje especial cuyas palabras y expresiones poseen la excepcional tipología del realismo grotesco. De esta forma, los estratos más profundos que sustentaron las formas embrionarias de la futura novela pueden ser hallados, interpretados y expresados mediante este específico mundo de los géneros serio-cómicos de la antigüedad.

\section{Notas}

1. La autora de este artículo aporta la traducción de las citas latinas. 
2. "[...] por si ignorante locutor habré ofendido en algo el lenguaje exótico y forense. Ya sin duda alguna, la misma variación de la voz responde estas cosas por la composición del inconstante conocimiento a que nos dedicamos" (Apuleyo: I-I).

3. "Y aunque con la cabeza inclinada hacia la tierra, en verdad hacia los mismos infiernos, caminara ya abatido, sin embargo, veo con una mirada de través, una cosa de máxima admiración, pues entre tantas miles de personas que se desbordaban, nadie había que no estallara completamente de risa" (Apuleyo: III-II).

4. "Sin demora, el pueblo que corría por todas partes, llenó las gradas con sorprendente rapidez; también habían abarrotado la entrada y todo el techo, y la mayor parte enlazados a las columnas, otros colgados de las estatuas, algunos semi visibles por las ventanas y el artesonado; sin embargo, todos eran indiferentes a los peligros con sorprendente afán digno de ser visto" (Apuleyo: III-II).

5. "Y no tomando en consideración un falso asunto y particularmente la paz de toda la ciudad [...] respetabilísimos Quirites. Porque conviene más a cada uno cuidadosamente que todos vosotros procuren por la dignidad pública que el criminal homicida, quien se ejercitó sanguinariamente de la carnicería de asesinatos, no habrá de ser enfrentado impunemente" (Apuleyo: III-III).

6. “[...] miro ese cruelísimo joven con la espada desenvainada ocupándose en la matanza indistintivamente, y ya tres muertos por su violencia moviéndose ante sus propios pies con los cuerpos aún palpitantes en gran cantidad de sangre" (Apuleyo: III-III).

7. "Pero por la providencia de dios, que no permite nada impune a los criminales, antes de que ese se escapara en sus marchas clandestinas, esperando temprano, me he preocupado conducirlo al gravísimo sacramento de vuestro juicio" (Apuleyo: III-III).

8. “[...] asesinados ante sus pies, moviéndose agitadamente los cuerpos aún palpitantes en gran cantidad de sangre. Así tenéis en frente al reo manchado en tanta sangre derramada, al reo sorprendido públicamente, al reo peregrino. Así pronuncien continuamente las sentencias por este crimen contra el hombre desconocido, porque también castigaríais severamente a un ciudadano vuestro" (Apuleyo III-III).

9. "Pues retirándome finalmente de la cena, serio, un poco borracho, porque no habré de negar exactamente en verdad mi crimen, regreso ante las mismas puertas del alojamiento -hacia el buen Milón, vuestro ciudadanos- veo varios ferocísimos ladrones, atacando la entrada y las puertas de la casa, deseando ardientemente arrancar los retorcidos quicios y todas las cerraduras que habían sido fijadas cuidadosísimamente, ya fuera de sí, más valientes, deliberando con la destrucción de los habitantes. Después, uno más dispuesto con el cuerpo más vigoroso con palabras dirigidas a la banda, incitaba a los restantes: "Eh muchachos, ataquemos a los que duermen con ánimos varoniles y agilidades de hombres" (Apuleyo: III-IV).

10. "Después el propio jefe y guía de los demás, habiéndome agredido con los fuertes hombres, allí mismo, soy arrastrado del cabello por ambas manos, y soy lanzado hacia atrás, y se arroja para exterminarme con una piedra. Mientras demanda que se la traigan, lo derribo golpeándolo felizmente con mano certera. Pero luego, a otro que estaba mordiéndome mis pies, lo acometo con un golpe temperado por la espalda, y al tercero que corría desprevenidamente, lo ataco en el pecho" (Apuleyo: III-VI).

11. "Así reivindicada la paz y la casa de los huéspedes y la salvación protegida de la comunidad, pensaba que no era tan culpable, sino también en verdad, habría de ser encomiado públicamente [...]" (Apuleyo: III-IV).

12. "[...] miro al frente a todo el pueblo -se derramaban por la risa a carcajadas- [...]" (Apuleyo: III-VII).

13. "Pues aquellos cadáveres de hombres asesinados eran tres odres hinchados y cortados con varios agujeros y, por lo que me recordaba mi lucha vespertina, rajados en estos lugares en donde había herido a aquellos ladrones" (Apuleyo: III-IX). 
14. "Entonces aquel de los que aguantando durante poco tiempo por la astucia, ya estalló de risa libremente entre la plebe. Estos se congracian por la nimiedad de la alegría, aquellos se apaciguan el dolor del vientre con la comprensión de las manos. Y ciertamente untados por la felicidad, y todos volviéndose a mirarme se alejan del teatro" (Apuleyo: III-X).

15. “[...] Fijado en piedra permanecí helado, no de otro modo, como una de las otras estatuas o columnas del teatro" (Apuleyo: III-X).

16. “[...] pues saca la presente tristeza de tu pecho y aparta la opresión del ánimo, pues este juego que públicamente celebramos cada año solemnemente por el agradabilísimo dios de la Risa, siempre florece con la novedad de la invención. Este dios acompañará propicio a su autor y conductor por todas partes, no permitirá afectuosamente que sufras de buen grado, sino bendecirá asiduamente tu propia frente con una gracia serena y toda la ciudad te ha ofrecido ilustres honores por esta gracia [...]" (Apuleyo: III-XX).

\section{Bibliografía}

Apulée. 1960. Metamorphoseon. Torino: Soc, per AZ G.B. Paravia \& C.

Apuleyo. 1990. El asno de oro. Madrid: Ediciones Cátedra.

Bajtín, Mijaíl. 1986. Problemas de la poética de Dostoievski. México D.F.: Fondo de Cultura Económica.

1991. Teoría de la novela. Madrid: Ediciones Taurus.

1995. La cultura popular en la Edad Media y el Renacimiento. El contexto de François Rabelais. Madrid: Alianza Editorial.

Barthes, Roland. 1974. La antigua retórica. Buenos Aires: Editorial Tiempo Contemporáneo.

Beristain, Helena. 2001. Diccionario de retórica y poética. México D.F: Editorial Porrúa.

García Gual, Carlos. 1988. Los orígenes de la novela. Madrid: Ediciones Istmo.

Marchese, Angelo y Joaquín Foradellas. 2000. Diccionario de retórica, crítica y terminología literaria. Barcelona: Editorial Ariel, S.A.

Monsalve, Alfonso. 1992. Teoría de la argumentación. Medellín: Editorial Universidad de Antioquia.

Rojas Rodríguez, Irene. 1997. El mundo carnavalesco y el plurilinguismo en Las metamorfosis de Apuleyo. Tesis de licenciatura: Universidad de Costa Rica.

Todorov, Zvetan. 1974. Introducción a la literatura fantástica. Buenos Aires: Editorial Tiempo Contemporáneo.

Walsh P.G. 1982. The later principate. Vol. II. V. New York: Cambridge University. 